\title{
PENGARUH KONSERVATISME AKUNTANSI, DEBT TO TOTAL ASSETS RATIO, LIKUIDITAS, PROFITABILITAS, DAN UKURAN PERUSAHAAN TERHADAP KUALITAS LABA
}

\author{
Christy Kurniawan, \\ Rosita Suryaningsih \\ Multimedia Nusantara, Indonesia \\ rosita@umn.ac.id
}

\begin{abstract}
The objective of th is research is to examine the effect of accounting conservatism, debt to total assets ratio, liquidity, profitability, and firm size both partially and simultaneously towards earnings quality. In this research, accounting conservatism was measured by CONACC, liqui dity was measured by current ratio, profitability was measured by return on assets, and firm size was measured by log total asset, while earnings quality was measured by earnings response coefficient. The objects of this study are manufacturing companies which were listed in Indonesia Stock Exchange for period 2013 until 2015. The sample are 39 companies determined based on purposive sampling. The data used in this study are secondary data such as financial statements and historical share prices. The testing method used in this research is multiple linear regression. The result off this study are (1) accounting conservatism has a positive significant effect towards earnings quality (2) debt to total assets ratio has a positive significant effect towards earnings quality (3) liquidity has no positive effects towards earnings quality (4) profitability has a positive significant effect towards earnings quality (5) firm size has no positive effects towards earnings quality (6) accounting conservatism, debt to total assets ratio, liquidity, profitability, and firm size simultaneously have a significant effect towards earnings quality.
\end{abstract}

Keywords: Accounting Conservatism, Debt to Total Assets ratio, Earnings Quality, Firm Size, Liquidity, Profitability

\section{PENDAHULUAN}

Menurut Ikatan Akuntan Indonesia (2014) dalam PSAK no. 1, laporan keuangan adalah suatu penyajian terstruktur dari posisi keuangan dan kinerja keuangan suatu entitas. Laporan keuangan menjadi media informasi yang digunakan perusahaan untuk mengkomunikasikan informasi keuangan perusahaan kepada pihak yang berkepentingan untuk mengambil k eputusan. Salah satu komponen laporan keuangan yang banyak mendapatkan perhatian adalah laporan laba rugi. Hal ini disebabkan karena didalam laporan laba $r$ ugi terdapat informasi mengenai laba yang dicapai oleh perusahaan dalam periode waktu tertentu. Informasi laba secara umum merupakan perhatian utama dalam menaksir kinerja dan pertanggungjawaban manajemen. Selain itu, laba juga dianggap sebagai informasi yang paling signifikan yang dapat memandu dalam proses pengambilan keputusan oleh pihak yang berkepentingan (So fian et al, 2011 dalam Tuwentina dan Wirama, 2014) .

Informasi laba ini penting bagi beberapa pihak seperti perusahaan, kreditor, dan investor. Bagi perusahaan, laba digunakan untu k kegiatan operasinya, meningkatkan kapasitas produksi, ekspansi, dan berinvestasi. Informasi laba juga di gunakan untuk menarik investor agar membeli saha $\mathrm{m}$ perusahaan sehingga perusahaan dapat memperoleh dana bagi kegiatan usahanya. Selain itu, laba juga diguna kan sebagai keputusan pencadangan dana, pembagian dividen kepada pemegang saham dan sebagai dasar perhitungan bonus bagi karyawannya. Bagi kreditor, laba digunakan untuk membuat keputusan pemberian kredit karena perusahaan dengan laba yang tinggi dinilai mem iliki kemampuan dalam membayar kewajibannya. 
Bagi investor, informasi laba digunakan sebagai dasar untuk membuat keputusan investasi yang tepat dalam membeli, menahan, atau men jual saham perusahaan. Informasi laba perusahaan tersebut merupakan salah satu informasi yang dapat memengaruhi respon investor dalam melakukan investasi. Respon tersebut disebabkan oleh keyakinan investor akan perusahaan yang menghasilkan laba yang tinggi, dinilai memiliki kinerja yang tinggi dan diharapkan dapat memberikan return yang menguntungkan, sedangkan perusahaan yang tidak menghasilkan laba dinilai tidak memiliki kinerja yang tinggi dan dianggap tidak dapat memberikan return yang menguntungkan untuk investor.

Sebagai contohnya adalah PT Unilever Indonesia Tbk, berdasarkan laporan keuangan yang dipublikasikan perseroan pada sem ster I/2016, perseroan mencatat laba senilai 3,30 triliun Rupiah atau tumbuh $12,62 \%$ dibandingkan dengan laba semester I/2015 yang tercatat 2,93 triliun Rupiah. Satrio Utomo, Kepala Riset PT Universal Broker Indonesia menyatakan saham Unilever sedang diburu banyak investor. Menurutnya, penguatan saham Unilever seiring dengan kinerja perseroan yang cukup baik. Penguatan saham Unilever ini terlihat dari data Bloomberg yang menunjukkan harga saham Unilever tercatat naik tajam 3,06\% dilevel Rp46.325 (bisnis.com). Dari contoh perusahaan tersebut terlihat bahwa laba perusahaan meningkat, harga saham juga meningkat. Hal tersebutt menunjukkan bahwa informasi laba dapat memengaruhi keputusan investor untuk berinvestasi yang terlihat dari meningkatnya harga saham perusahaan.

Selain itu, pasar modal padaa tahun 2011-2015 semakin berkembang, hal ini dilihat dari meningkatnya jumlah perusahaan go public yan g terdaftar di Bursa Efek Indonesia (BEI). Dengan meningkatnya jumlah perusahaan go public ini membuat bertambahnya pilihan investasi yang dapat dipilih oleh investor. Maka dari itu, agar investor dapat membuat keputusan investasi yang tepat, investor perlu memperhatikan kualitas laba perusahaan. Kualitas laba adalah kemampuan informasi laba dalam memengaruhi keputusan investor dalam berinvestasi.

Dalam penelitian ini kualitas laba diproksikan dengan Earnings Response Coefficient (ERC). Menurut Cho dan Jung (1991) dalam Yuniarta (2013), pengertian Earnings Response Coefficient adalah pengaruh setiap dollar unexpected earnings terhadap return saham, yang ditunjukkan melalui slope koefisien dalam regresi abnormal return saham dan unexpected earnings. ERC merupakan respon pasar terhadap informasi laba yang diumumkan oleh perusahaan yang dilihat dari selisih return perusahaan dan return pasar. Kuatnya respon pasar terhadap informasi laba akan tercermin dari tingginya $E R C$ dan $E R C$ yang tinggi mengindikasikan tingginya kualitas laba perusahaan.

Konservatisme merupakan sebuah prinsip kehati-hatian dalam mengakui aktiva dan laba karena aktivitas ekonomi dan bisnis yang dilingkupi ketidakpastian (Wibowo, 2002 dalam Gayatri dan Suputra, 2013). Dalam penelitian ini, konservatisme akuntansi diproksikan dengan Conservatism Based On Accrued Items (CONACC).

Dalam pengukuran $C O N A C C$, apabila nilai arus kas kegiatan operasi yang diperoleh dari total aset perusahaan lebih besar dari laba bersih yang juga diperoleh dari total aset perusahaan maka hal tersebut mengindikasikan bahwa perusahaan memiliki kecukupan kas. Kecukupan kas tersebut dapat dilihat oleh investor sebagai potensi perusahaan untuk membagikan dividen. Hal ini akan membuat investor merespon positif dengan membeli saham perusahaan sehingga jumlahh permintaan saham dan harga saham akan meningkat. Harga saham yang meningkat akan berdampak pada meningkatnya return aktual saham sehingga abnormal return meningkat. Meningkatnya abnormal return menunjukkan investor memberikan respon yang tinggi terhadap informasi laba yang diumumkan perusahaan sehingga menunjukkan laba yang berkualitas. Penelitian Tuwentina dan Wirama (2014) menunjukkan konservatisme akuntansi berpengaruh positif terhadap kualitas laba.

Debt to total asset ratio digunakan untuk mengukur seberapa besar total aset yang didanai kreditor (Kieso et al, 2015). Debt to total asset atio yang rendah mengindikasikan rendahnya total aset yang dibiayai dari pinjaman kreditor. Rendahnya tingkat pinjaman menurunkan tingkat risiko kegagalan perusahaan dalam mengembalikan pinjaman. Rendahnya tingkat pinjaman mengindikasikan perusahaan mempunyai kewajiban yang rendah sehingga dana dapat dialokasikan untuk kegiatan operasi dalam jumlah yang lebih besar. Dengan meningkatnya kegiatan operasi perrusahaan diharapkan laba perusahaan juga akan me ningkat. Meningkatnya laba perusahaan mengindikasikann meningkatnya kinerja operasional perusahaan, sehingga diharapkan perusahaan mampu untuk membagikan dividen. Hal ini akan membuat investor merespon positif dengan membeli saham perusahaan sehingga jumlah permintaan saham dan harga saham akan meningkat. Harga saham yang meningkat akan berdampak pada meningkatnya return aktual saham sehingga abnormal return 
meningkat. Meningkatnya abnormal return menunjukkan investor memberikan respon yang tinggi terhadap informasi laba yang diumumkan perusahaan sehingga menunjukkan laba yang berkualitas. Penelitian Yuniarta (2013) menunjukkan bahwa risiko kegagalan utang (default risk) berpengaruh negatif terhadap kualitas laba.

Likuiditas adalah kemampuaan jangka pendek perusahaan untuk membayar kewaajiban yang telah jatuh tempo dan untuk memenuhi kebutuhan kas yang tak terduga (Kieso et al, 2015). Dalam penelitian ini, likuiditas diproksikan dengan current ratio. Current ratio yang tinggi mengindikasikan tingginya kemampuan perusahaan dalam membayar utang jangka pendeknya dengan aset lancar yang dimilikinya. Tingginya aset lancar perusahaan menunjukkan tingginy a ketersediaan dana jangka pendek yang dapat digunakan untuk kegiatan operasinya sehingga diharapkan dapat meningkatkan laba perusahaan. Meningkatnya laba perusahaan mengindikasikan meningkatnya kinerja operasional perusahaan sehingga perusahaan diharapkan mampu untuk membagikan dividen. Hal tersebut akan membuat investor merespon positif dengan membeli saham perusahaan sehingga jumlah permintaan saham dan harga saham akan meningkat. Harga saham yang meningkat akan berdampak pada meningkatnya return aktual saham sehingga abnormal return me ingkat. Meningkatnya abnormal return menunjukkan investor memberikan respon yang tinggi terhadap informasi laba yang diumumkan perusahaan sehingga menunjukkan laba yang berkualitas. Wulansari (2013) menunjukkan bahwa likuiditas berpengaruh positif terhadap kualitas laba.

Profitabilitas adalah ukuran untuk mengukur pendapatan atau keberhasilan operasi dari sebuah perusahaan untuk periode waktu te rtentu (Kieso et al, 2015). Dalam penelitian ini, profitabilitas diproksikan dengan rasio Return On Asset ( $R O A$ ). ROA yang tinggi mengindikasikan tingginya kemampuan perusahaan dalam menghasilkan laba menggun akan total aset yang dimilikinya sehingga perusahaan dapat memperoleh laba tinggi. Laba yang tinggi mengindik asikan tingginya kinerja operasional perusahaan. Dengan tingginya kinerja operasional perusahaan, diharapka $\mathrm{n}$ perusahaan mempunyai kemampuan untuk mem bagikan dividen. Hal tersebut akan membuat investor merespon positif dengan membeli saham perusahaan sehingga jumlah permintaan saham dan harga saham meningkat. Harga saham yang meningkat akan berdampak pada meningkatnya return aktual saham sehingga abnormal return meningkat. Meningkatnya abnormal return menunjukkan investor memberikan respon yang tinggi terhadap informasi laba yang diumumkan perusahaan sehingga menunjukkan laba yang berkualitas. Penelitian Risdawaty dan Subowo (2015) menyatakan bahwa profitabilitas berpengaruh terhadap kualitas laba.

Ukuran perusahaan merupakan suatu skala dimana dapat diklasifikasikan besar kecilnya perusahaaan menurut berbagai cara antara lain dengan ukuran penjualan, total aset, dan kapitalisasi pasar (Widayanti et al, 2014). Dalam penelitian ini, ukuran perusahaan diproksikan dengan menghitung logaritm natural dari total aset perusahaan. Semakin besar ukuran perusahaan, semakin besar total aset yang dimiliki perusahaan sehingga semakin besar sumber daya yang dapat digunakan untuk kegiatan operasinya. Dengan semakin besar sumber daya yang dapat digunakan untuk kegiatan operasi, produksi perusahaan akan semakin meningkat sehingga akan memperoleh pendapatan yang tinggi dan mengeluarkan beban sesuai dengan kebutuhan kegiatan operasional (efisien). Dengan demikian, diharapkan laba perusahaan akan meningkat. Meningkatnya laba perusahaan mengindikasikan meningkatnya kinerja operasional perusahaan sehingga perusahaan diharapkan mampu untuk membagikan dividen. Hal tersebut akan membuat investor merespon positif dengan membeli saham perusahaan sehingga jumlah permintaan saham dan harga saham akan meningkat. Harga saham yang meningkat akan berdampak pada meningkatnya return aktual saham sehingga abnormal return meningkat. Meningkatnya abnormal return menunjukkan investor memberikan respon yang tinggi terhadap informasi laba yang diumumkan perusahaan sehingga menunjukkan laba yang berkualitas. Penelitian Dira dan Astika (2014) menunjukkan adanya pengaruh positif antara ukuran perusahan dengan kualitas laba. Akan tetapi dalam penelitian Widayanti et al (2014), ukuran perusahaan berpengaruh negatif terhadap kualitas laba.

Berdasarkan latar belakang yang telah diuraikan, adapun rumusan masalah dari penelitian ini adalah sebagai berikut:

1. Apakah konservatisme akuntan si yang diproksikan dengan $C O N A C C$ berpengaruh positif terhadap kualitas laba?

2. Apakah debt to total assets ratio berpengaruh negatif terhadap kualitas laba? 
3. Apakah likuiditas yang diproksikan dengan current ratio berpengaruh positif terhadap kualitas laba ?

4. Apakah profitabilitas yang diproksikan dengan return on asset berpengaruh positif terhadap kualitas laba?

5. Apakah ukuran perusahaan berpengaruh positif terhadap kualitas laba ?

\section{KERANGKA TEORI DAN PENGEMBANGAN HIPOTESIS}

2.1. Laporan Keuangan

Menurut Ikatan Akuntan Indonesiaa (IAI) (2014) dalam PSAK no. 1, laporan keuangan adalah suatu penyajian terstruktur dari posisi keuangan da n kinerja keuangan suatu entitas. Namun, menurut Putri dan Supadmi (2016), laporan keuangan merupakan catat an informasi keuangan suatu perusahaan pada suatu periode akuntansi yang dapat digunakan untuk menggam barkan kinerja perusahaan. Menurut IAI (2014) dalam Kerangka Dasar Penyusunan dan Penyajian Laporan Keuangan, pengguna laporan keuangan meliputi investor sekarang dan investor potensial, karyawan, pemberi pinjaman, pemasok dan kreditor usaha lainnya, pelanggan, pemerintah serta lembaga-lembaganya, dan masyarakat. Mereka menggunakan laporan keuangan untuk memenuhi beberapa kebutuhan informasi yang berbeda. Laporan keuangan terdiri dari beberapa komponen. Menurut IAI (2014) dalam PSAK no. 1, laporan keuangan yang lengkap terdiri dari:

a. Laporan posisi keuangan pada akhir periode.

b. Laporan laba rugi dan penghas ilan komprehensif lain selama periode.

c. Laporan perubahan ekuitas selama periode.

d. Laporan arus kan selama periode.

e. Catatan atas laporan keuangan, berisi ringkasan kebijakan akuntansi yang signifikan dan informasi penjelasan lain.

f. Laporan posisi keuangan pada awal periode terdekat sebelumnya ketika entitas menerapkan suatu kebijakan akuntansi secara retrrospektif atau membuat penyajian kembali pos-pos lap oran keuangan.

\subsection{Teori Sinyal}

Teori sinyal menjelaskan bahwa informasi merupakan unsur penting bagi investor dan pelaku bisnis karena informasi pada hakekatnya menya jikan keterangan, catatan atau gambaran baik untuk keadaan masa lalu, saat ini maupun keadaan masa yang akan datang bagi kelangsungan hidup perusahaan dan bagaimana dampaknya terhadap perusahaan (Rahayu dan Suaryana, 2015). Informasi yang dipublikasikan sebagai suatu pengumuman akan memberikan signal bagi investor dalam pengambilan keputusan investasi. Jika pengumuman tersebut mengandung nilai positif, maka diharapkan pasar akan bereaksi pada waktu pengumuman tersebut diterima oleh pasar (Jogiyanto, 2000 dalam Arisanti dan Daljono, 2014).

Susilowati dan Turyanto (2011) berpendapat bahwa teori sinyal juga mengemukakan tentang bagaimana seharusnya sebuah perusahaan memberikan sinyal kepada pengguna laporan keuangan. Sinyal tersebut berupa informasi mengenai kondisi perusahaan kepada pemilik ataupun pihak yang berkepentingan. Sinyal yang diberikan dapat juga dilakukan melalui pengungkapan informasi akuntansi seperti laporan keuangan, laporan apa yang sudah dilakukan oleh manajemen untuk merealisasikan keinginan pemilik, atau bahkan dapat berupa promosi serta informasi lain yang menyatakan bahwa perusahaan tersebut lebih baik dari pada perusahaan lain.

\subsection{Kualitas Laba}

Menurut Kieso et al (2015), dalam mengevaluasi kinerja keuangan suatu perusahaan, kualitas laba perusahaan sangat penting untuk dianalisis. Perusahaan yang memiliki kualitas laba yang tinggi akan menyediakan informasi lengkap dan transparan dan tidak akan membingungkan atau menyesatkkan pengguna laporan keuangan. Menurut Paramita (201 2), kualitas laba dapat 
diindikasikan sebagai kema mpuan informasi laba memberikan respon kepada pasar. Dengan kata lain, laba yang dilaporkan memiliki kekuatan respon (power of response).

Kualitas laba sebagai salah satu karakteristik yang penting dari sistem pelaporan keuangan. Kualitas laba yang tinggi dikatakan untuk meningkatkan efisiensi pasar modal, sehingga investor dan pengguna lain tertarik pada informasi laporan keuangan (Ewert dan Wagenhofer, 2009 dalam Nurhanifah dan Jaya, 2014).

\subsection{Earnings Response Coefficient}

Cho dan Jung (1991) dalam Yuniarta (2013), mendefinisikan Earnings Response Coefficient sebagai pengaruh setiap dollar laba kejutan (unexpected earnings) terhadap return saham, yang ditunjukkan melalui slope efficient dalam regresi abnormal return saham dengan unexpected earnings. $E R C$ juga didefinisikan oleh Scott (2003) dalam Dira dan Astika (2014) sebagai ukuran tingkat abnormal return sekuritas dalam merespon komponen unexpected earnings yang dilaporkan dari perusahaan yang mengeluarkan sekuritas tersebut. Menurut Bruegger dan Dunbar (2009) dalam Tuwentina dan Wirama (2014), koefisien respon pada dasa rnya merupakan suatu upaya untuk memahami bagaimana suatu informasi dapat mempengaruhi harga saham.

Jika kualitas laba semakin baik atau persisten di masa depan, maka prediksi nilai $E R C$ akan semakin tinggi. Jadi $E R C$ dapat menunjukkan baik buruknya kualitas laba tergantung pada abnormal return saham yang dilihat dari naik turunnya harga saham dan harga pasar berdasarkan laba yang diperoleh perusahaan (Sandi, 2013). Kuatnya respon pasar terhaadap informasi laba terlihat dari tingginya Earning s Response Coefficient (ERC) yang mengindikasikan kualitas laba (Wulandari dan Herkulanus, 2015).

\subsection{Konservatisme Akuntansi}

1.

Konservatisme akuntansi adalah prinsip kehati-hatian dalam mengakui keuntungan dan segera mengakui kerugian dan utang yang mempunyai kemungkinan akan terjadi (Watts, 2003 dalam Untari dan Budiasih, 2014). Adapun menurut Oktomega h (2012), konservatisme adalah reaksi yang cenderung mengarah pada sikap kehati-hatian atau disebut prudent reaction dalam menghadapi ketidakpastian yang melekat dalam perusahaan dan melingkupi aktivitas bisnis dan ekonomi untuk mencoba memastikan bahwa kettidakpastian dan risiko inheren yang menjadi ancaman dalam lingkungan bisnis sudah cukup dipertimbangkan.

Hendriksen et al (2000) dalam Biki et al (2013), menjelaskan dua argumen yang dipakai untuk mendukung konservatisme dalam menghadapi ketidakpastian. Pertama, sikap pesimistik dianggap perlu untuk menetralkan sikap optimistik berlebihan yang ada pada para manajer dan pemilik. Kedua, overstatem ent laba dan aset jauh lebih berbahaya daripada understatement. Tuwentina dan Wirama (2014), menduga tedapat pengaruh positif konservatisme akuntansi pada kualitas laba. Hal ini disebabkan oleh prinsip-prinsip konservatisme yang berpihak kepada investor dengan cenderung bersifat melindungi investor dari kesalahan berinvestasi akibat kekeliruan dalam menganalisis informasi laba perusahaan.

Hasil penelitian Tuwentin a dan Wirama (2014) dan Wulandari dan Herkulanus (2015) menunjukkan bahwa konservatisme berpengaruh positif terhadap kualitas laba. Hal ini terlihat dari hasil regresi yang menunjukkan bahwa konservatisme berpengaruh positif signifikan pada $E R C$. Hipote sis alternatif penelitian mengenai pengaruh konservatisme terhadap kualitas laba dapat dinyatakan sebagai beriku t:

\section{$\mathrm{Ha}_{1}$ : Konservatisme akuntansi yang diproksikan dengan $\mathrm{CONACC}$ berpengaruh positif terhadap kualitas laba.}




\subsection{Debt to Total Assets Ratio}

Debt to total assets ratio (DTA) termasuk dalam solvency ratio yang mengukur kemampuan perusahaan untuk jangka waktu yang panjang. Debt to total asset ratio digunakan untuk mengukur sebera pa besar total aset yang didanai oleh kreditur (Kieso et al ,2015). Semakin tinggi rasio ini maka pendanaan dengan utang semakin banyak, maka semakin sulit bagi perusahaan untuk memperoleh tambahan pinjaman karena dikhawatirkan perusahaan tidak mampu menutu piutang-utangnya dengan aktiva yang dimilikinya. Sebaliknya semakin rendah rasio ini maka semakin kecil perusahaan dibiayai dari utang (Gunawan dan Wahyuni, 2013). Indra et al (2011) menyatakan bahwa besarnya hutang menunjukkan kualitas perusahaan serta prospek yang kurang baik pada masa mendatang. Untuk perusahaan dengan hutang yang banyak, peningkatan laba akan menguatkan posisi dan keamanan bondholder daripada pemegang saham.

Penelitian Yuniarta (2013) menemukan bahwa risiko kegagalan utang (default risk) berpengaruh negatif terhadap kualitas laba (ERC). Hasil penelitian Rahayu dan Suaryana (2015) menunjukkan bahwa risiko gagal bayar berpengaruh pada koefisien respon laba. Hipotesis alternatif penelitian mengenai pengaruh debt to total assets ratio terhadap kualitas laba dapat dinyatakan sebagai berikut:

$\mathrm{Ha}_{2}$ : Debt to Total Assets Ratio berpengaruh negatif terhadap kualitas laba.

\subsection{Likuiditas}

Likuiditas adalah kemampuan su atu perusahaan untuk memenuhi hutang jangka pendeknya dengan aktiva lancar yang dimiliki (Irawati, 2012 ). Adapun pengertian menurut Kieso et al (2013), rasio likuiditas digunakan untuk mengukur kemampuan jangka pendek perusahaan untuk membayar kewajiban yang telah jatuh tempo dan untuk memenuhi kebutuhan kas yang tak terduga. Salah satu alat ukur yang $\mathrm{d}$ apat digunakan untuk menentukan tingkat likuiditas adalah current ratio. Menurut Kieso et al (2015), currrent ratio adalah suatu ukuran yang sering digunakan untuk mengevaluasi likuiditas perusahaan dan kema mpuan melunasi utang jangka pendek. Semakin tinggi current ratio menunjukkan keefektifan perusahaan dalam melunasi kewajiban jangka pendeknya (Rice, 2016).

Menurut Jang et al (2007) da lam Wulansari (2013), perusahaan dengan likuiditas tinggi akan memiliki risiko yang relatif kecil sehingga kreditur merasa yakin dalam memberikan pinjaman kepada perusahaan dan investor akan tertarik untuk mengi nvestasikan dananya ke perusahaan tersebut karena investor yakin bahwa perusahaan mampu bertahan (tidak dilikuidasi). Dengan demikian pada saat laba dipublikasikan pasar akan merespon positif laba tersebut. Hasil penelitian Wulansari (2013) menunjukkan bahwa likuiditas yang diukur dengan current ratio berpengaruh positif terhadap kualitas laba. Namun, hasil penelitian Irawati (2012) dan Nurhanifah dan Jaya (2014) menemukan bahwa likuiditas berpengaruh negatif terhaddap kualitas laba yang diproksikan dengan ERC. Hipotesis alternatif penelitian mengenai pengaruh likuiditas terhadap kualitas laba dapat dinyatakan sebagai berikut:

$\mathrm{Ha}_{3}$ : Likuiditas yang diproksikan dengan current ratio berpengaruh positif terhadap kualitas laba.

\subsection{Profitabilitas}

Menurut Kieso et al (2015), rasio profitabilitas adalah mengukur pendapatan atau keberhasilan operasi dari sebuah perusahaan untuk periode waktu tertentu. profitabilitas merupakan rasio yang mengukur kemampuan para eksekutif perusahaan dalam menciptakan tingkat keuntungan baik dalam bentuk laba perusahaan maupun nilai ekonomis atas penjualan, aset bersih perusahaan maupun modal sendiri (shareholde $r$ equity). Profitabilitas perusahaan diukur dengan menggunakan rasio Return on Asset (ROA) yang menggambarkan sejauh mana kemampuan aset-aset yang dimiliki perusahaan bisa menghasilkan laba (Setiawa ti et al, 2014). Adapun menurut Kusmuriyanto (2014), $R O A$ adalah salah satu bentuk dari rasio profitabilitas untuk mengukur kemampuan perusahaan dalam menghasilkan laba yang menggunakan total aktiva yang ada dan setelah biaya-biaya modal dikeluarkan dari analisis.

Menurut Risdawaty dan Subowo (2015), Para investor cenderung akan menanamkan modalnya pada perusahaan yang memiliki tingkat laba yang cukup tinggi dibandingkan dengan perusahaan yang 
memiliki tingkat laba rendah. Bagi investor perusahaan yang memiliki tingkat laba yang tinggi dinilai mampu menghasilkan laba yang maksimal. hal ini menunjukan bahwa profitabilitas berpengaruh positif pada earnings response coefficient. Hasil penelitian Aryanti dan Sisdyani (2016) dan Gaol (2014 ) menunjukkan bahwa profitabilitas berpengaruh positif terhadap kualitas laba. Namun, hasil penelitian Risdaw aty dan Subowo (2015) memberikan hasil bahwa profitabilitas berpengaruh negatif terhadap kualitas laba, sedangkan hasil penelitian Kusmuriyanto (2014) menunjukkan bahwa profitabilitas tidak berpengaruh terhadap kualitas laba. Hipotesis alternatif penelitian mengenai pengaruh profitabilitas terhadap kualitas laba dapat dinyatakan sebagai berikut:

\section{$\mathrm{Ha}_{4}$ : Profitabilitas yang diproksikan dengan return on asset berpengaruh positif terhadap \\ kualitas laba.}

\subsection{Ukuran Perusahaan}

Menurut Irawati (2012), ukuran perusahaan adalah suatu ukuran perusahaan yang dapat diklasifikasikan besar kecilnya perusahaan menurut log size. Ukuran perusahaan merupakan besar kecilnya perusahaan yang dapat dilihat melalui jumlah aktiva secara keseluruhan yang dimiliki oleh perusahaan. Perusahaan besar dapat ditunjukkan dengan aktiva yang besar pula. ukuran perusahaan (size) adalah variabel yang diproksikan dengan total aset perusahaan. Total aset dipilih sebagai proksi ukuran perusahaan karena tujuan penelitian mengukur ukuran ekonomi perusahaan.

Dira dan Astika (2014) berpendapat bahwa, perusahaan besar memiliki tingkat pengembalian (return) dan informasi yang lebih besar. Oleh sebab itu, investor lebih percaya kepada perusaha an besar dibandingkan perusahaan kecil dengan harapan memperoleh keuntungan (return) yang besar pula. Semakin tinggi kepercayaan investor, maka semakin tinggi pula kualitas laba yang diukur dengan $E R C$. Hasil penelitian Dira dan Astika (2014) dan Sandi (2013) menunjukkan bahwa ukuran perusahaan berpengaruh positif pada kualitas laba yang diukur dengan $E R C$ sedangkan hasil penelitian Irawati (2012) menunjukkan ukuran perusahaan tidak berpengaruh terhadap kualitas laba. Hipotesis alternatif penelitian mengenai pengaruh ukuran perusahaan terhadap kualitas laba dapat dinyatakan sebagai berikut:

\section{Ha $_{5}$ : Ukuran perusahaan berpengaruh positif terhadap kualitas laba.}

\section{METODOLOGI PENELITIAN}

Objek penelitian yang digunakan dalam penelitian ini adalah perusahaan manufaktur y ang terdaftar di Bursa Efek Indonesia (BEI). Perusahaan manufaktur adalah perusahaan industri yang mengolah komponen bahan baku dan mengkonversikannya menjadi barang jadi (Horngren et al, 2015). Di BEI perusah aan manufaktur terbagi menjadi 3 sektor yaitu sektor industri dasar dan kimia, aneka industry, dan industri barang konsumsi.

Penelitian ini merupakan penelitian causal study. Causal study adalah penelitian yang dilakukan untuk melihat hubungan sebab-akibat antar variiabel-variabel (Sekaran dan Bougie, 2013). Masalah yang diteliti adalah melihat variabel dependen yaitu kualitas laba perusahaan go public yang dapat dipengaruhi oleh konservatisme akuntansi, debt to total asset ratio, likuiditas, profitabilitas dan ukuran perusahaan.

Variabel dependen dalam penelitian ini adalah kualitas laba. Kualitas laba adalah kemampuan informasi laba dalam memengaruhi keputusan innvestor dalam berinvestasi. Pada penelitian ini kualitas laba diukur dengan earnings response coefficient. E arnings response coefficient merupakan koefisien yang diperoleh dengan meregresi nilai saham dan laba akuntansi. Cummulative Abnormal Return (CAR) digunakan sebagai proksi saham, Unexpected Return (UE) digunakan sebagai proksi laba akuntansi (Wulandari dan Herkulanus, 2015). Berikut ini adalah rumus Cummul ative Abnormal Return (CAR) (Delvira dan Nelvirita, 2013):

$$
\mathrm{CAR}_{\mathrm{it}}=\Sigma \mathrm{AR}_{\mathrm{it}}
$$

Keterangan:

$C A R_{\text {it }}=$ Cummulative Abnormal Return perusahaan i selama periode amatan 15 hari dari tanggal publikasi laporan keuangan (15 hari sebelum, 1 hari tanggal publikasi, 15 hari setelah tanggal publikasi).

$A R_{i t}=$ Abnormal Return perusahaan i pada hari t. 
Berikut rumus Abnormal Return (AR) (Daud dan Syarifuddin, 2008 dalam Nurhanifah dan Jaya, 2014):

Keterangan:

$$
A R_{\mathrm{it}}=R_{\mathrm{it}}-R_{\mathrm{mt}}
$$

$A R_{\mathrm{it}} \quad=$ Abnormal Return sekuritas perusahaan i pada hari $\mathrm{t}$.

$R_{i t} \quad=$ return sesungguhnya perusahaan i pada hari $\mathrm{t}$.

$R M_{\mathrm{t}} \quad=$ return pasar pada hari t.

Untuk memperoleh data abnormal return, terlebih dahulu mencari return saham harian dan return pasar harian. Berikut rumus return saham harian (Nurhanifah dan Jaya, 2014):

$$
\mathrm{R}_{\mathrm{it}}=\frac{\mathrm{P}_{\mathrm{it}}-\mathrm{P}_{\mathrm{it}-1}}{\mathrm{P}_{\mathrm{it}-1}}
$$

Keterangan:

$R_{\text {it }} \quad=$ return saham sesungguh nya perusahaan i pada hari $\mathrm{t}$

$\mathrm{P}_{\mathrm{it}} \quad=$ harga penutupan saham perusahaan i pada hari $\mathrm{t}$

$\mathrm{P}_{\mathrm{it}-1} \quad=$ harga penutupan sahamperusahaan i sehari sebelum hari $\mathrm{t}$

Berikut ini adalah rumus return pasar harian (Nurhanifah dan Jaya, 2014):

Keterangan:

$$
\mathrm{Rm}_{\mathrm{t}}=\frac{\mathrm{IHSG}_{\mathrm{t}}-\mathrm{IHSG}_{\mathrm{t}-1}}{\mathrm{IHSG}_{\mathrm{t}-1}}
$$

$R m_{\mathrm{t}} \quad=$ Return pasar pada hari $\mathrm{t}$.

$\mathrm{IHSG}_{\mathrm{t}}=$ Indeks Harga Saham Gabungan pada hari t.

$\mathrm{IHSG}_{\mathrm{t}-1}=$ Indeks Harga Saham Gabungan sehari sebelum hari t.

Unexpected Earnings diukur menggunakan pengukuran laba per saham (Kurnia dan Sufiyati, 2015).

Berikut adalah rumus Unexpected Earning s (Kurnia dan Sufiyati, 2015):

$$
\mathrm{UE}_{\mathrm{it}}=\frac{\mathrm{EPS}_{\mathrm{it}}-\mathrm{EPS}_{\mathrm{it}-1}}{\mathrm{EPS}_{\mathrm{it}-1}}
$$

Keterangan:

$\mathrm{UE}_{\mathrm{it}} \quad=$ Unexpected Earnings perusahaan i pada tahun $\mathrm{t}$.

$\mathrm{EPS}_{\text {it }}=$ laba per saham perusahaan i pada tahun $\mathrm{t}$

EPSit-1 = laba per saham perusaha an i setahun sebelum tahun $\mathrm{t}$.

Earnings Response Coefficient (ERC akan dihitung dari slope $\beta$ hubungan Car dengan UE (Daud dan Syarifuddin, 2008 dalam Nurhanifah dan Jaya, 2014). Berikut perhitungan ERC :

$$
\mathrm{CAR}_{\mathrm{it}}=\alpha+\beta \mathrm{UEit}+\varepsilon
$$

Keterangan:

$\mathrm{UE}_{\text {it }} \quad=$ Unexpected Earnings perusahaan i pada tahun $\mathrm{t}$.

$C A R_{\mathrm{it}}=$ Cummulative Abnormal Return perusahaan i selama periode $\mathrm{t}$

$\beta=$ Koefisien Respon Laba

$\varepsilon \quad=$ error term

Variabel independen dalam penelitian ini ada lima dan semua variabel independen tersebut diukur dengan menggunakan skala rasio. Berikut ini adalah variabel independen yang digunakan dalam penelitian ini. 
Konservatisme akuntansi adalah prinsip kehati-hatian dalam mengakui aset dan laba, namun segera mengakui beban dan kewajiban karena aktivitas bisnis dan ekonomi dilingkupi oleh ketidakpastian. Konservatisme diukur berdasarkan adaptasi dari Givoly dan Hayn (2000) Conservatism Based On Accrued Items. Berikut rumus penghitungan konservatisme (Savitri, 2016):

Keterangan:

$$
\mathrm{CONACC}=\frac{\mathrm{NI}+\mathrm{DEP}-\mathrm{CFO}) \times(-1)}{\mathrm{TA}}
$$

$\begin{array}{ll}\text { CONACC } & =\text { Conservatism Based On Accrued Items } \\ N I & =\text { Laba tahun berjalan } \\ D E P & =\text { Beban penyusutan asset tetap } \\ \text { CFO } & =\text { Arus kas dari aktifitas operasi } \\ \text { TA } & =\text { Total Aset }\end{array}$

Debt to total assets ratio (DTA) adalah rasio yang digunakan untuk mengukur seberapa besar total aset yang didanai kreditor. Berikut rumus Debt to total assets ratio (DTA) (Kieso et al, 2015):

DTA $=\frac{\text { Total Debt }}{\text { Total Aset }}$

Likuiditas adalah kemampuan perusahaan dalam memenuhi utang jangka pendek dengan mengkonversi asetnya menjadi kas. Dalam penelitian ini likuiditas akan di ukur dengan current ratio. Current ratio adalah rasio yang digunakan untuk me ngukur kemampuan perusahaan dalam memenuhi utang jangka pendek menggunakan aset lancar yang di milikinya. Berikut rumus current ratio (Kieso et al, 2015):

\begin{tabular}{ccc|}
\hline $\mathrm{CR}$ & Total Aset Lancar \\
Total Kewajiban Lancar
\end{tabular}

Profitabilitas adalah kemampuan perusahaan dalam menghasilkan laba selama periode tertentu. Pada penelitian ini profitabilitas diproksikan dengan Return on Asset (ROA). ROA mennunjukkan kemampuan perusahaan dalam menghasilkan laba menggunakan aset yang dimiliki oleh perusahaan. Berikut rumus perhitungan ROA (Kieso et al, 201 5):

ROA $=\frac{\text { Laba Tahun Berjalan }}{\text { Rata-rata Total Aset }}$

Ukuran perusahaan adalah suatu pengukuran mengenai besar kecilnya perusahaan, yang diukur dengan menggunakan total aset. Menurut Rahayu dan Suaryana (2015), ukuran perusahaan diukur dengan menggunakan rumus:

$$
\text { Size } \quad=\quad \text { Ln Total Aset }
$$

Data sekunder dalam penelitia $\mathrm{n}$ ini adalah data sekunder berupa laporan keuangan perusahaan manufaktur periode 2013-2015 dan data harga saham perusahaan. Jenis data yang diambil adalah laporan keuangan perusahaan yang sudah di-audit oleh auditor independen. Data ini dikumpulkan dengan mengambil dari www.idx.co.id yang merupakan situs resmi dari Bursa Efek Indonesia dan http://finance.y ahoo.com/.

Teknik pengambilan sampel y ang digunakan dalam penelitian ini adalah metode purposive sampling. Kriteria perusahaan-perusahaan yang akan menjadi sampel dari penelitian ini adalah:

1. Perusahaan manufaktur yang terdaftar di BEI berturut-turut selama periode 2013-2015 .

2. Menerbitkan laporan keuangan tahunan per tanggal 31 Desember periode 2013-2015 yang telah diaudit oleh auditor independen.

3. Laporan keuangan yang menggu nakan mata uang Rupiah selama periode 2013-2015.

4. Memperoleh laba berturut-turut selama periode 2013-2015. 
5. Mempunyai total aset diatas 1 Triliun berturut-turut selama periode 2013-2015.

Penelitian ini melakukan uji hipotesis dengan menggunakan regresi linier berganda, dengan sebelumnya telah melakukan uji normalitas dan uji asumsi klasik.

\section{HASIL}

\subsection{Objek Penelitian}

Objek penelitian ini diambil deng an menggunakan teknik purposive sampling berdasar kan kriteria yang telah ditentukan pada perusahaan manu faktur yang terdaftar di Bursa Efek Indonesia (BE I) periode 2013-2015. Tabel 4.1 menunjukkan rincian pengambilan sampel perusahaan yang digunakan dalam penelitian ini.

Tabel 4.1

Rincian Pengambilan Sampel Penelitian

\begin{tabular}{lc}
\hline \multicolumn{1}{c}{ K eterangan } & Jumlah Perusahaan \\
\hline Perusahaan manufaktur yang terdaftar di BEI berturut-turut selama periode & $\mathbf{1 3 6}$ \\
2013-2015 & $\mathbf{1 3 1}$ \\
Perusahaan manufaktur yang menerbitkan laporan keuangan tahunan per & \\
tanggal 31 Des ember periode 2013-2015 yang telah di-audit oleh auditor & \\
independen. & $\mathbf{1 0 4}$ \\
Laporan keuangan yang menggunakan mata uang Rupiah selama periode & \\
2013-2015. & $\mathbf{6 4}$ \\
Memperoleh laba berturut-turut selama periode 2013-2015 & $\mathbf{3 9}$ \\
Mempunyai total aset diata s 1 Triliun berturut-turut selama periode 2013- & \\
Jumlah perusahaan yang digunakan sebagai sampel penelitian & $\mathbf{3 9}$ \\
\hline
\end{tabular}

\subsection{Statistik Deskriptif}

Statistik deskriptif memberikan gambaran tentang data penelitian. Berikut ini adalah hasil statistic deskriptif variable-variabel dalam penelitian ini :

Tabel 4.2

\section{Hasil Statistik Deskriptif \\ Descriptive Statistics}

\begin{tabular}{|c|c|c|c|c|c|c|}
\hline & $\overline{\mathrm{N}}$ & $\overline{\text { Rang } \epsilon}$ & $\overline{\text { Minimum }}$ & Maximun & $\overline{\text { Mear }}$ & $\begin{array}{r}\text { Std } \\
\text { Deviatior }\end{array}$ \\
\hline ERC & 117 & 3.0671 & $-1.944 €$ & 1.1226 & -.049627 & .5185561 \\
\hline CONACC & 117 & 1.4094 & $-.626 c$ & .7835 & $-.03172 \leftleftarrows$ & .1155811 \\
\hline DTA & 117 & $.812 \approx$ & .0692 & .8815 & .412771 & 1748447 \\
\hline CR & 117 & 12.4807 & $.513 s$ & $12.994 €$ & $2.53761 \varepsilon$ & $2.110192 C$ \\
\hline ROA & 117 & .7975 & $.000 \varepsilon$ & $.798 ق$ & .118964 & $.111857 \approx$ \\
\hline $\begin{array}{l}\text { SIZE } \\
\text { Valid N } \\
\text { (listwise) }\end{array}$ & 117 & $5.440 \mathrm{~s}$ & 27.6932 & 33.1341 & 29.349311 & $1.344706 \mathrm{c}$ \\
\hline
\end{tabular}

Berdasarkan hasil statistik deskriptif pada Tabel 4.2, jumlah observasi kualitas laba yang diproksikan $E R C$ adalah 117 dan nilai range $E R C$ sebesar 3,0671. Nilai $E R C$ terendah adalah -1,9446 sedangkan nilai $E R C$ tertinggi adalah 1,1226. Rata-rata kualitas laba perusahaan yang diproksikan dengan $E R C$ adalah -0,049627. Nilai standar deviasi $E R C$ adalah sebesar 0,5185567. Jumlah observasi untuk konservatisme akuntansi yang diproksikan dengan CONACC adalah 117 dan nilai range CONACC sebesar 1,4049. Nilai CONACC terendah adalah $-0,6260$ pada tahun 2014 , sedangkan nilai CONACC tertinggi adalah 0,7835 . $\mathrm{R}$ ata-rata konservatisme akuntansi yang diproksikan dengan 
CONACC adalah -0,031725. Nilai standar deviasi $C$ ONACC adalah sebesar 0,1155811. Jumlah observasi untukk debt to total assets ratio (DTA) adalah 117 dan nilai range DTA sebesar 0,8123. Nilai $D T A$ terendah adalah 0,0692 sedangkan nilai $D T A$ tertinggi adalah 0,8815 . Rata-rata $D T A$ adalah 0,4112771 . Nilai standar deviasi DTA adalah sebesar 0,1748447. Jumlah observasi untuk likuiditas yang diproksikan dengan current ratio $(C R)$ adalah 117 dan nilai range $C R$ sebesar 12,4807 . Nilai $C R$ terendah adalah 0,5139 sedangkan nilai $C R$ tertinggi adalah 12,9946. Rata-rata $C R$ adalah 2,537618. Nilai standar deviasi $C R$ adalah sebesar 2,1101920. Jumlah observasi untuk profitabilitas yang diproksikan dengan return on assets (ROA) adalah 117 dan nilai range $R O A$ sebesar 0,7975 . Nilai $R O A$ terendah adalah 0,0008 sedangkan nilai $R O A$ tertinggi adalah 0,7983 . Rata-rata $R O A$ adalah 0,118964 . Nilai standar deviasi $R O A$ adalah sebesar 0,1118573 . Jumlah observasi untuk ukuran per usahaan (SIZE) adalah 117 dan nilai range SIZE sebeesar 5,4409. Nilai SIZE terendah adalah 27,6932 sedangkan nilai SIZE tertinggi adalah 33,1341. Rata-rata SIZE adalah 29,349311. Nilai standar deviasi SIZE adalah sebesar 1,3447069.

\subsection{Uji Normalitas}

Hasil uji normalitas dengan menggunakan uji non-parametrik Kolmogorov-Smirnov adalah sebagai berikut:

Tabel 4.3

Hasil Uji Normalitas

\begin{tabular}{llr}
\hline & & Unstandardized Residual \\
\hline $\mathrm{N}$ & & 100 \\
Normal Parameters & Mean &, 0000000 \\
& Std. Deviation &, 36917917 \\
Most Extreme Differences & Absolute &, 118 \\
& Positive & 078 \\
& Negative &,- 118 \\
Test Statistic & & 1,176 \\
Asymp. Sig. (2-tailed) & &, 126 \\
\hline
\end{tabular}

Berdasarkan Tabel 4.3 dapat diketahui bahwa nilai Kolmogorov-smirnov adalah 1,176 dengan nilai signifikansi sebesar 0,126 yang menunjukkan bahwa data residual terdistribusi normal karena nilai signifikansi residual yang dihasilkan lebih besar dari 0,05 .

\subsection{Uji Multikolonieritas}

Hasil uji multikolonieritas dengan melihat nilai tolerance dan VIF adalah sebagai berikut :

Tabel 4.4

Hasil Uji Multikolonieritas

\begin{tabular}{llrr}
\hline Model & & \multicolumn{2}{c}{ Collinearity Statistics } \\
\cline { 3 - 4 } & & Tolerance & VIF \\
\hline 1 & (Constant) & & \\
CONACC &, 910 & 1,099 \\
& DTA &, 434 & 2,304 \\
& sqrtCR &, 425 & 2,354 \\
& sqrtROA &, 732 & 1,367 \\
& Lg10SIZE &, 950 & 1,053 \\
\hline
\end{tabular}

Tabel 4.4 menunjukkan nilai tolerance untuk seluruh variabel independen berada diatas nilai 0,10 dan nilai VIF berada kurang dari 10, sehingga dapat dinyatakan bahwa tidak terjadi multikolonieritas dalam penelitian ini, yang berarti tidak terdapat kolerasi antar variabel independen dari penelitian ini, yaitu a ntara $C O N A C C, D T A, C R, R O A$ dan SIZE dalam model regresi. 


\subsection{Uji Autokolerasi}

Hasil pengujian autokorelasi dengan menggunakan Run Test adalah sebagai berikut:

Tabel 4.5

Hasil Uji Autokorelasi

Runs Test

\begin{tabular}{lr}
\hline & \multicolumn{2}{c}{ Unstandardized } \\
& Residual \\
\hline Test Value & 01030 \\
Cases $<$ Test Value & 50 \\
Cases $>=$ Test Value & 50 \\
Total Cases & 100 \\
Number of Runs & 44 \\
Z & $-1,407$ \\
Asymp. Sig. (2-tailed) &, 159 \\
\hline
\end{tabular}

Berdasarkan Tabel 4.5 terlihat bahwa nilai test adalah sebesar 0,01030 dengan nilai signifikansi 0,159. Maka dari itu dapat dinyatakan bahwa tidak terjadi autokorelasi pada penelitian ini karena nilai signifikansi lebih dari 0,05 , yang artinya tidak terdapat korelasi antara kesalahan pengganggu pada periode $t$ dengan kesalahan pengganggu pada periode $\mathrm{t}-1$ (sebelumnya).

\subsection{Uji Heteroskedastisitas}

Berikut ini merupakan hasil uji heteroskedastisitas:

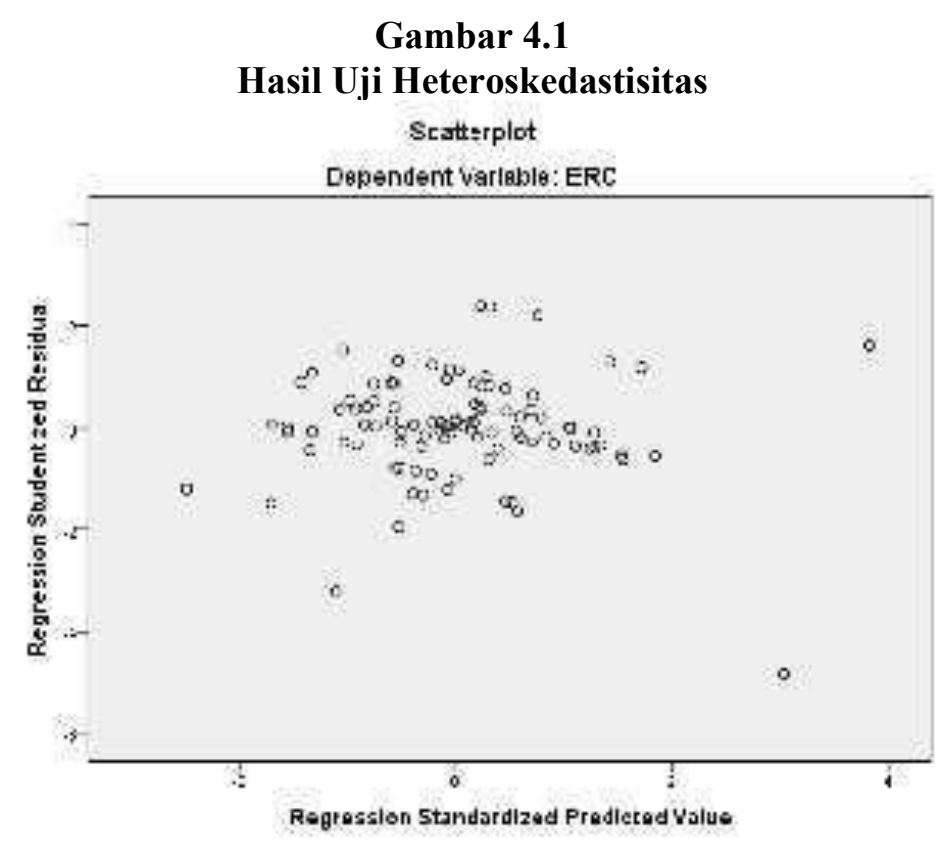

Berdasarkan grafik Scatterplot pada Gambar 4.1 terlihat bahwa titik-titik menyebar secara acak dan tersebar baik di atas maupun di bawah a gka 0 pada sumbu $\mathrm{Y}$ dan tidak membentuk pola tertentu (bergelombang, melebar kemudian menyempit). Oleh karena itu dapat disimpulkan bahwa tidak terjadi heteroskedastisitas dalam penelitian ini. 


\subsection{Uji Koefisien Determinasi (Adjusted $\left.\boldsymbol{R}^{2}\right)$}

Tabel 4.6

Hasil Uji Koefisien Determinasi

\begin{tabular}{ccccc}
\hline Model & $\mathrm{R}$ & R Square & Adj. R Square & $\begin{array}{c}\text { Std. Error of the } \\
\text { Estimate }\end{array}$ \\
\hline 1 &, $379^{\mathrm{a}}$ &, 143 &, 098 &, 3788706 \\
\hline
\end{tabular}

Berdasarkan Tabel 4.6, nilai koefisi en korelasi (R) bernilai positif yang menunjukkan hubungan antara variabel dependen yaitu kualitas laba dengan variabel independen yaitu konservatisme akunta nsi (CONACC), DTA, likuiditas $(C R)$, profitabilitas (ROA), dan ukuran perusahaan (SIZE) adalah hubungan y ang searah. Selain itu, nilai R berada pada interval koefisien 0,20-0,3999 yaitu sebesar 0,379 . Hal ini menunjukkan bahwa hubungan antara variabel dependen dan independen rendah dalam penelitian ini.

Nilai koefisien determinasi (Adjusted $R$ Square) adalah sebesar 0,098. Hal ini menunjukkan kemampuan variabel konservatisme akuntansi $(C O N A C C), D T A$, likuiditas $(C R)$, profitabilitas $(R O A)$, dan ukuran perusahaan (SIZE) untuk menjelaskan variabel kualitas laba $(E R C)$ adalah sebesar 9,8\% sedangkan sisanya sebesar $90,2 \%$ dijelaskan oleh variabel lain diluar model yang tidak diteliti dalam penelitian ini.

\subsection{Uji Signifikansi Simultan (Uji Statistik F)}

Berikut ini merupakan hasil uji signifikansi simultan :

Tabel 4.7

Hasil Uji Signifikansi Simultan

\begin{tabular}{|c|c|c|c|c|c|c|}
\hline & Model & $\begin{array}{l}\text { Sum of } \\
\text { Square }\end{array}$ & df & $\begin{array}{c}\text { Mean } \\
\text { Square }\end{array}$ & $\mathrm{F}$ & Sig. \\
\hline \multirow{3}{*}{1} & Regression & 2,259 & 5 &, 452 & 3,147 & ,011 \\
\hline & Residual & 13,493 & 94 & ,144 & & \\
\hline & Total & 15,752 & 99 & & & \\
\hline
\end{tabular}

a. Dependent Variable: ERC

b. Predictors: (Constant), lg10SIZE, sqrtCR, CONACC, sqrtROA, DTA

Hasil uji statistik F pada Tabel 4.7 menunjukkan nilai $\mathrm{F}$ sebesar 3,147 dan tingkat signifikansi berada dibawah 0,05 yaitu 0,011 . Hal ini menunjukkan bahwa model regresi ini layak dan pembuktian hipotesis dapat dilanjutkan. Selain itu, nilai signif ikansi dibawah 0,05 menunjukkan bahwa model regresi dapat digunakan untuk memprediksi kualitas laba $\left(\begin{array}{ll}E & R C\end{array}\right)$ atau dapat dikatakan bahwa konservatisme akun tansi yang diproksikan dengan $C O N A C C$, DTA, likuiditas yang diproksikan dengan current ratio, profitabilitas yang diproksikan dengan return on asset, dan ukuran perusahaan secara simultan berpengaruh signifikan terhadap kualitas laba.

\subsection{Uji Signifikansi Parameter Individual (Uji Statistik t)}

Berikut ini merupakan hasil uji sig nifikansi parameter individual:

Tabel 4.8

Hasil Uji Signifikansi Parameter Individual

\begin{tabular}{|c|c|c|c|c|c|c|}
\hline & \multirow{2}{*}{ Model } & \multicolumn{2}{|c|}{$\begin{array}{l}\text { Unstandardized } \\
\text { Coefficients }\end{array}$} & \multirow{2}{*}{$\begin{array}{c}\begin{array}{c}\text { Standardized } \\
\text { Coefficients }\end{array} \\
\text { Beta }\end{array}$} & \multirow[t]{2}{*}{$\mathrm{t}$} & \multirow[t]{2}{*}{ Sig. } \\
\hline & & $\mathrm{B}$ & $\begin{array}{c}\text { Std. } \\
\text { Error }\end{array}$ & & & \\
\hline \multirow{6}{*}{1} & (Constant) &, 394 & 3,120 & &, 126 & ,900 \\
\hline & CONACC & 1,317 &, 653 & ,202 & 2,107 & ,047 \\
\hline & DTA & ,898 & ,351 & 371 & 2,558 & 012 \\
\hline & SqrtCR &, 097 & , 138 & 103 &, 702 & ,484 \\
\hline & SqrtROA & 1,102 & ,369 & ,334 & 2,989 & ,004 \\
\hline & $\lg 10 \mathrm{SIZE}$ &,- 812 & 2,117 &,- 038 &,- 383 & ,702 \\
\hline
\end{tabular}


Berdasarkan Tabel 4.8 diperoleh persamaan regresi dalam penelitian ini yaitu:

$$
E R C=0,202 C O N A C C+0,371 D T A+0,103 C R+0,334 R O A-0.038 S I Z E
$$

Berdasarkan hasil uji statistik t yang telah dilakukan, nilai koefisien regresi untuk variabel konservatisme akuntansi yang diproksikan dengan CONACC adalah sebesar 0,202, yang berarti bahwa setiap kenaikan 1 Rupiah konservatisme akuntansi akan menyebabkan kenaikan kualitas laba sebesar $20,2 \%$. Nilai t CONACC sebesar 2,017 dengan nilai signifikansi yang lebih kecil dari 0,05 yaitu s ebesar 0,047 . Dengan demikian, dapat dinyatakan bahwa konservatisme akuntansi yang diproksikan dengan CONACC memiliki pengaruh positif secara signifikan terhadap kualitas laba sehingga $\mathrm{Ha}_{1}$ diterima. Hasil penelitian ini konsisten dengan hasil penelitian Tuwentina dan Wirama (2014) yang menunjukkan bahwa konservatisme akuntansi berpengaruh positif signifikan terhadap kualitas laba.

Nilai koefisien regresi unttuk variabel Debt to Total Assets Ratio (DTA) adalaah sebesar 0,371, yang berarti bahwa setiap kenaikan $1 \%$ debt to total assets ratio akan menyebabkan kenaikan kualitas laba sebesar 37,1\%. Nilai t DTA sebesar 2,558 dengan nilai signifikansi yang lebih rendah dari 0,05 yaitu sebesar 0,012 . Dengan demikian, dapat dinyatakann bahwa DTA berpengaruh positif signifikan terhadap kualitas laba. Namun, karena tidak searah dengan hipotesis, maka $\mathrm{Ha}_{2}$ ditolak. Hal ini disebabkan karena dengan semakin besar utang perusahaan, semakin besar dana yan g dapat digunakan untuk kegiatan operasi perusahaan. Contohnya adalah PT Unilever Indonesia Tbk (UNVR) yang pada tahun 2014 mengalami peningkatan jumlah utang sebesar 10,41\% dan harga pokok penjualan pada tahun 2013 dan 2014 adalah Rp14.978.947.000.000 dan Rp17.304.613.000.000. Selain itu, laba pada tahun 2013 adalah Rp 5.352.625.000.000 dan tahun 2014 adalah Rp5.926.720.000.000. Dari data tersebut terlihat bahwa dengan jumlah utang yang meningkat, perusahaan dapat menggunakan pinjaman tersebut untuk mendanai kegiatan operasinya yang terlihat dari harga pokok penjualan yang meningkat. Harga pokok penjualan yang meningkat menunjukkan jumlah produk yang dihasilkan bertambah sebesar $15,53 \%$. Selain itu, laba juga meningkat sebesar $10,71 \%$ sehingga menarik respon investor untuk berinvestasi. Oleh karena itu, DTA berpengaruh positif terhadap kualitas laba. Has il ini konsisten dengan hasil penelitian Risdawaty dan Subowo (2015) yang menunjukkan hasil penelitian $D T A$ berpengaruh positif terhadap kualitas laba.

Nilai koefisien regresi unntuk variabel likuiditas yang diproksikan dengan current ratio adalah 0,103 , yang berarti bahwa setiap kenaikan $1 \%$ current ratio akan menyebabkan kenaikan kualitas laba sebesar $10,3 \%$. Nilai t $C R$ sebesar 0,702 dengan nilai signifikansi diatas 0,05 yaitu 0,484 . Dengan demikian dapat dinyatakan bahwa likuiditas yang diproksikan dengan current ratio tidak memiliki pengaruh positif terhadap kualitas laba sehingga $\mathrm{Ha}_{3}$ ditolak. Hal ini disebabkan karena sebagian besar perusahaan dalam penelitian ini memiliki tingkat kas yang rendah dalam komponen aset lancarnya dan komponen aset lancar terbesarnya adalah persediaan. Salah satu contohnya adalah PT Hanjaya Mandala Sampoerna Tbk (HMSP) tahun 2015 dengan $C R$ sebesar 6,5674, perusahaan m empunyai kas sebesar Rp1.718.738.000.000 dan total aset lancar Rp29.807.330.000.000. Dari data tersebut terlihat bahwa kas perusahaan hanya sebesar $5,77 \%$ dari total aset lancarnya yang dapat digunakan untuk kegiatan operasinya. Hal tersebut membuat tingkat produksi perusahaan yang telihat dari cost of goods sold pada tahun 2015 hanya meningkat sebesar 11,82\% (dalam hal ini cost of goods sold tahun 2014 dan 2015 adalah Rp60.190.077.000.000 dan Rp67.304.917.00 0.000). Selain itu, laba perusahaan juga hanya meningk at sebesar $1,79 \%$ (dalam hal ini laba tahun 2014 dan 2015 adalah Rp10.181.083.000.000 dan Rp10.3 63.308.000.000. Dari data tersebut terlihat bahwa laba perusahaan tidak menunjukkan pertumbuhan laba yaang signifikan yakni hanya 1,79\% sehingga tidak m enarik respon investor untuk berinvestasi. Hasil penelitian ini konsisten dengan penelitian Dira dan Astika (2014) yang menunjukkan bahwa likuiditas tidak berpengaruh terhadap kualitas laba.

Nilai koefisien regresi u ntuk variabel profitabilitas yang diproksikan dengan return on assets adalah 0,334 , yang berarti bahwa setiap kenaikan $1 \%$ return on assets akan menyebabkan kenaikan kualitas laba sebesar 33,4\%. nilai t $R O A$ sebesar 2,989 dengan nilai signifikansi dibawah 0,05 yaitu 0 ,004. Dengan demikian dapat dinyatakan bahwa profitablilitas yang diproksikan dengan return on assets memiliki pengaruh positif terhadap kualitas laba sehingga $\mathrm{Ha}_{4}$ diterima. Hasil penelitian ini konsisten dengan penelitian Risdawaty dan Subowo (2015) menunjukkan bahwa profitabilitas berpengaruh positif terhadap kualitas laba.

Nilai koefisien regresi untuk variabel ukuran perusahaan adalah $-0,038$, yang berarti bahwa setiap kenaikan 1 ukuran perusahaan akan menyebabkan penurunan kualitas laba sebesar 3,8\%. Nilai $\mathrm{t}$ ukuran perusahaan sebesar $-0,383$ dengan nilai signifikansi diatas 0,05 yaitu 0,702 . Dengan dem ikian 
dapat dinyatakan bahwa ukuran perusahaan tidak me miliki pengaruh positif terhadap kualitas laba sehingga $\mathrm{Ha}_{5}$ ditolak. Hal ini disebabkan karena total aset yang digunakan sebagai sumber daya untuk kegiatan operasi, dalam hal ini adalah aset tetap perusahaan, jumlahnya relatif kecil. Contohnya adalah PT Hanjaya Mandala Sampoerna Tbk (HMSP) tahun 2015, terlihat bahwa aset tetap yang digunakan jumlahnya relatif kecil yaitu Rp 6.281.176.000.000 dari Rp38.010.724.000.000 atau 16,52\% dari seluruh total aset yang dimiliki perusahaan. Hal ini membuat perusahaan memiliki kemampuan yang terbatas untuk meningkatkan produksi di mana produksi hanya meningkat sebesar 11,82\% yang dapat dilihat dari cost of goods sold. Penjualan HMSP juga meningkat, namun peningkatan penjualan diiringi dengan meningkatnya beban usaha yang lebih tinggi dari periode sebelumnya, dalam hal ini jumlah pendapatan dan beban tahun 2015 sama-sama meningkat sebesa $\mathrm{r}$ 10,38\% dan 12,16\%. Ketidakmampuan perusahaan dalam meningkatkan pendapatan lebih tinggi dari bertambahnya beban yang dikeluarkan menunjukkan bahwa perusahaan tidak mampu mengelola bebannya secara efisien sehingga beban yang dikeluarkan tidak sesuai dengan kebutuhan perusahaan untuk meningkatkan penjualan dan laba perusahaan. Hal ini terlihat dari pertumbuhan laba yang tidak signifikan, hanya meningkat sebesar 1,79\%. Hal dengan hasil penelitian Irawati $(2012)$ yang menunjukkan ukuran perusahaan tidak berpengaruh terhadap kualitas laba.

\section{SIMPULAN, IMPLIKASI, DAN KETERBATASA N \\ 5.1 Simpulan}

Simpulan yang diperoleh dari hasil penelitian adalah sebagai berikut:

1. Ha diterima, yang berarti konservatisme akuntansi yang diproksikan dengan CONACC memiliki pengaruh positif secara signifikan terhad ap kualitas laba.

2. $\mathrm{Ha}_{2}$ ditolak karena tidak searah dengan hipotesis, yang berarti DTA berpengaruh positif signifikan terhadap kualitas laba.

3. $\mathrm{Ha}_{3}$ ditolak, yang berarti likuid itas yang diproksikan dengan current ratio tidak memiliki pengaruh positif terhadap kualitas laba.

4. $\mathrm{Ha}_{4}$ diterima, yang berarti profitablilitas yang diproksikan dengan return on assets memiliki pengaruh positif terhadap kualitas laba.

5. $\mathrm{Ha}_{5}$ ditolak, yang berarti ukuran perusahaan tidak memiliki pengaruh positif terhadap kualitas laba.

6. Dari hasil uji statistic $\mathrm{F}$, mode 1 regresi memenuhi kelayakan karena nilai signifikansinya berada dibawah 0,05 yaitu 0,011 . Hal ini menunjukkan bahwa model regresi dapat digunakan untuk memprediksi pengaruh konservatisme akuntansi yang diproksikan dengan CONACC, debt to total assets ratio, likuditas yang diproksikan dengan current ratio, profitabilitas yang diproksikan dengan return on assets, dan ukuran perusahaan terhadap kualitas laba secara simultan dan signifikan mempengaruhi kualitas laba.

\subsection{Implikasi}

Implikasi dari penelitian ini yaitu terkait kualitas laba, para investor dan juga pengguna informasi laporan keuangan lainnya harus memperti mbangkan faktor konservatisme akuntansi (CONACCC), debt to total assets ratio, profitabilitas yang diproksikan dengan return on assets, dan ukuran perusahaan di karenakan faktor-faktor tersebut berpengaruh secara signif ikan terhadap kualitas laba perusahaan. Hal ini m engindikasikan bahwa factor-faktor tersebut harus diperti mbangkan ketika para pengguna laporan keuangan khususnya investor akan membuat keputusan investasi pada perusahaan terkait.

\subsection{Keterbatasan}

Berdasarkan penelitian yang telah dilakukan, terdapat beberapa keterbatasan yaitu:

1. Hasil penelitian ini tidak dapat digeneralisasi untuk seluruh perusahaan yang terdaftar di Bursa Efek Indonesia (BEI) sepanjang periode karena perusahaan yang diteliti merupakan perusahaan sektor manufaktur yang terdaftar di B EI periode 2013-2015.

2. Hasil penelitian ini merupakan seluruh perusahaan manufaktur yang terdaftar di BEI dan tidak semua termasuk perusahaan dengan saham blue chip yang berada pada kapitalisasi pasar yang sama sehingga respon investor sulit dilihat dalam jangka waktu yang pendek dan membuat data tida k normal. 
3. Kemampuan variabel independen dalam menjelaskan variasi variabel independen dapat dilihat dari nilai adjusted $R$ square sebesar $9,8 \%$.

4. Hasil penelitian pada variabe 1 likuiditas dengan menggunakan proksi current ratio tidak berpengaruh terhadap kualitas laba.

\subsection{Saran}

Dengan memperhatikan keterbatasan penelitian yang telah dijabarkan sebelumnya, maka saran untuk penelitian selanjutnya adalah:

1. Memperluas objek penelitian dengan menambah sektor perusahaan lainnya, seperti sektor jasa.

2. Menggunakan objek penelitian lain seperti perusahaan yang termasuk dalam indeks LQ45 maupun Kompas100 sebagai sampel penelitian.

3. Menambah variabel independen lain dalam penelitian, seperti investment opportuunity set, pertumbuhan laba, dan kualitas audit.

4. Menggunakan proksi cash ratio untuk variabel likuditas.

\section{DAFTAR PUSTAKA}

Arisanti, Lupita Ade dan Daljono. 2014. "Pengaruh Tingkat Pengungkapan Sukarela terhadap Nilai Perusahaan". Diponegoro Journal of Accounting. Vol.3 No.3, 2014, Hal. 1-8.

Astri, Riendy. 2017. KINERJA S EMESTER I: Laba Unilever Indonesia (UNVR) Tumbuh 12,62\%, Harga Saham Naik Tajam. Dalam http://market.bisnis.com/ read/20160727/192/569425/kkinerja-semester-i-laba-unilever-indonesia-unvr-tumbuh-1262harga-saham-naik-tajam.

Biki, Reyther. 2013. "Pengaruh Konservatisme Akuntansi terhadap Asimetri Informasi Dimorasi Kepemilikan Manajerial dan Kepemilikan Institusional". Jurnal Analisis. Vol. 2 No. 2, Dese mber 2013, Hal. $162-170$.

Dira, Kadek Prawisanti dan Ida Bagus Putra Astika. 2014. "Pengaruh Struktur Modal, Likuiditas, Pertumbuhan Laba, dan Ukuran Perusaha an pada Kualitas Laba". E-Journal Akuntansi Universitas Udayana. Vol. 7 No. 1, 2014, Hal. 64-78.

Gayatri, Ida Ayu Sri dan I Dewa Gede Dharma Suputra. 2013. "Pengaruh Corporat e Governance, Ukuran Perusahaan dan Leverage T erhadap Integritas Laporan Keuangan". E-Journal Akuntansi Universitas Udayana. Vol. 5 No. 1, 201 3, Hal 345-360.

Indra, A. Zubaidi et al. 2011. "Analisis Faktor - Faktor yang Mempengaruhi Earnings Response Coefficient (ERC): Studi pada Perusaha an Properti dan Real Estate yang Terdaftar di Bursa Efek Indonesia”. Jurnal Akuntansi dan Keuangan. V ol. 16 No.1, Januari-Juni 2011, Hal. 1-22.

Ikatan Akuntan Indonesia. 2014. St andar Akuntansi Keuangan. Jakarta: Salemba Empat.

Irawati, Dhian Eka. 2012. "Pengaruh Struktur Modal, Pertumbuhan Laba, Ukuran Perusahaan dan Likuiditas terhadap Kualitas Laba". Accounting Analysis Journal. Hal. 1-6.

Kieso, Donald E. et al. 2015. Financial Accounting IFRS Edition. USA: Wiley.

Kurnia, Ivan dan Sufiyati. 2015. "Pengaruh Ukuran Perusahaan, Leverage, Risiko Sistematik dan Investment Opportunity Set terhadap Earning Response Coefficient pada Perusahaan Manufaktur yang Terdaftar di Bursa Efek Indonesia pada Tahun 2012-2014”. Jurnal Ekonomi. Vol. XX No.03, November 2015, Hal 463-478. 
Kusmuriyanto. 2014. "Pengaruh Struktur Modal, Ukuran Perusahaan, Likuditas dan Return On Asset terhadap Kualitas Laba". Accounting Analysis Journal. Hal. 26-33.

Nurhanifah, Yoga Anisa dan Tre sno Eka Jaya. 2014. "Pengaruh Alokasi Pajak antar Periode, Investment Opportunity Set dan Likuiditas terhadap Kualitas Laba". Jurnal Ilmiah Wahana A kuntansi. Vol. 9 No.2, Desember 2014, Hal 109-13 3.

Oktomegah, Calvin. 2012. "Faktor-Faktor yang Mempengaruhi Penerapan Konservatisme pada Perusahaan Manufaktur di BEI”. Jurnal Ilmiah Mahasiswa Akuntansi. Vol.1 No.1, Januari 201 2, Hal. $36-42$.

Paramita, Ratna Wijayanti Daniar. 2012. "Pengaruh Leverage, Firm Size, dan Voluntary Disclousure terhadap Earnings Response Coefficient". Jurnal WIGA. Vol.2 No.2, September 2012, Hal. 103 -118 .

Putri, A.A Ayu Ganitri dan Ni Luh Supadmi. 2016. "Pengaruh Tingkat Hutang dan K epemilikan Manajerial terhadap Persistensi Laba pada Perusahaan Manufaktur". E-Jurnal Akuntansi Universitas Udayana. Vol.15 No.2, Hal. 915-942.

Rahayu, L.P. Agustina Kartika dann I.G.N Agung Suaryana. 2015. "Pengaruh Ukuran Perusahaan dan Risiko Gagal Bayar pada Koefisien Respon Laba". E-Journal Akuntasi Universitas U dayana. Vol.13 No.2, Novemver 2015, Hal. 665-6 84.

Rice, Agustina. 2016. "Analisa Faktor-Faktor yang Memperngaruhi Pertumbuhan Laba dengan Ukuran Perusahaan sebagai Variabel Moderating”. Jurnal Wira Ekonomi Mikroskil. Vol. 6 No. 1.

Risdawaty, Iin Mutmainah Eka dan Subowo. 2015. "Pengaruh Struktur Modal, Ukuran Perusahaan, Asimetri Informasi, dan Profitabilitas terhadap Kualitas Laba”. Jurnal Dinamika Akuntansi. Vol. 7 No.2, September 2015, Hal 109-11 8.

Sandi, Khoerul Umam. 2013. "Faktor-faktor yang Mempengaruhi Earnings Response Coefficient". Accounting Analysis Journal.

Savitri, Enni. 2016. Konservatisme Akuntansi Cara Pengukuran, Tinjauan Empiris dan Faktor-faktor yang Mempengaruhinya. Yogyaka rta: Pustaka Sahila.

Sekaran, Uma dan Roger Bougie. 2013. Research Methods for Business: A Skill-Building Approach. USA:Wiley.

Setiawati, Erma et al. 2014. “Analisa Pengaruh Ukuran, Pertumbuhan dan Profitabilitas Perusahaan terhadap Koefisien Respon Laba (Studi Empiris pada Perusahaan Manufaktur yang Te rdaftar di Bursa Efek Indonesia (BEI) tahun 2009-2011". Research Methods and Organizational Studies . Hal 175-188.

Susilowati, Yeye. 2011. "Reaksi Signal Rasio Profitabilitas dan Rasio Solvabilitas terhadap Return Saham Perusahaan”. Dinamika Keu angan dan Perbankan. Vol. 3 No., 2011, Hal 17-37.

Tuwentina, Putu dan Dewa Gede Wirama. 2014. "Pengaruh Konservatisme Akuntansi dan Good Corporate Governance pada Kualitas Laba". E-Journal Akuntasi Universitas Udayana. Vol. 8 No.2, 2014, Hal 185-201.

Untari, Made Dewi Ayu dan I G usti Ayu Nyoman Budiasih. 2014. "Pengaruh Konservatisme Laba dan Voluntary Disclousure terhhadap Earnings Response Coefficient". E-Journal Akuntasi Universitas Udayana. Vol. 7 No.1, 2014 , Hal.1-18. 
Widayanti et al. 2014. "Faktor-Faktor yang Mempengaruhi Kualitas Laba pada Perusahaan High Profile yang Terdaftar di BEI". Jurnal Dinamika Ekonomi \& Bisnis. Vol.11 No.1, Maret 2014, Hal 46-64.

Wulandari, Ida Ayu Triesni dan Bambang Suprasto Herkulanus. 2015. "Konservatisme Akuntansi, Good Corporate Governance dan Pengungkapan Corporate Social Responbility pada Earnings Response Coefficient". E-Journal Akuntasi Universitas Udayana. Vol. 13 No.1, 2015, Hal. 173 $-190$.

Wulansari, Yenny. 2013. "Pengaruh Investment Opportunity Set, Likuiditas dan Leverage terhadap Kualitas Laba pada Perusahaan Manufaktur yang Terdaftar di BEI.”. E-Journal Universitas Negeri Padang. 